\title{
EFEKTIVITAS PELAYANAN ADMINISTRASI KEPENDUDUKAN DI KELURAHAN BUNUT KABUPATEN SANGGAU
}

\author{
ADE RISNA SARI \\ Universitas Tanjungpura \\ e-mail: aderisnasari73@gmail.com
}

\begin{abstract}
ABSTRAK
Penelitian ini adalah tentang pelayanan administrasi kependudukan di kelurahan Bunut kecamatan Kapuas kabupaten Sanggau provinsi Kalimantan Barat. Alasan peneliti mengambil lokasi tersebut adalah dengan pertimbangan bahwa lokasi penelitian ini letaknya dekat dengan ibu kota kabupaten Sanggau dimana kelurahan Bunut ini merupakan kelurahan yang letaknya di bagian terdepan dekat dengan pintu gerbang masuk kota Sanggau. Adapun permasalahan yang diteliti adalah sejauh mana efektivitas pelayanan administrasi kependudukan yang diberikan oleh kelurahan Bunut kepada masyarakat sekitarnya dalam pembuatan administrasi kependudukan dimana yang menjadi fokus penelitian adalah kinerja pegawai kelurahan dengan permasalahan yang ada seperti permasalahan tata cara pelayanan, rendahnya pendidikan pegawai, kurangnya sarana dan prasarana, kurangnya jumlah pegawai dan disiplin kerja pegawai di kelurahan. Hasil penelitian ini menggambarkan bahwa belum efektifnya pelayanan administrasi kependudukan di kelurahan Bunut dikarenakan faktor kurangnya sarana dan prasarana di kantor kelurahan dan masih kurangnya sumber daya manusia (SDM). Penelitian ini menggunakan pendekatan kualitatif dengan metode deskriftif dan teknik pengumpulan datanya dengan triangulasi data.
\end{abstract}

Kata Kunci : efektivitas, pelayanan, administrasi kependudukan, kelurahan

\section{ABSTRACT}

This research is about population administration services in Bunut sub-district, Kapuas district, Sanggau regency, West Kalimantan province. The reason why the researchers took this location is the consideration that the location of this research is close to the capital city of Sanggau district where Bunut is a sub-district that is located at the forefront close to the entrance gate of Sanggau city. The problem under research is the extent to which the effectiveness of population administration services provided by Bunut sub-district to the surrounding community in making population administration where the focus of the research is the performance of sub-district employees with existing problems such as service procedures, low employee education, lack of facilities and infrastructure, lack of number of employees and working discipline of employees in the sub-district. The results of this research illustrated that the ineffectiveness of population administration services in Bunut village is due to the lack of facilities and infrastructure at the village office and the lack of human resources (HR). This research used a qualitative approach with descriptive methods and data collection techniques with data triangulation.

Keywords: effectiveness, service, population administration, sub-district

\section{PENDAHULUAN}

Efektivitas pelayanan kepada masyarakat menjadi perhatian bagi setiap lembaga Pemerintah Daerah.Peran serta aparatur pemerintah daerah menjadi sorotan bagi masyarakat dalam memberikan pelayanan. Sesuai dengan Undang-Undang Nomor 23 Tahun 2014 tentang Pemerintahan Daerah, dimana Pemerintah Daerah diberikan kewenangan yang demikian luas oleh Pemerintah Pusat untuk mengatur rumah tangga daerahnya sendiri, termasuk didalamnya adalah pemberian pelayanan kepada masyarakat di daerahnya. Pemerintah daerah yang dimaksud yaitu kelurahan. Kelurahan merupakan wilayah kerja lurah sebagai perangkat daerah kabupaten/kota dalam wilayah kecamatan. Pelayanan yang ada di kelurahan salah satunya berupa pelayanan administrasi kependudukan. Administrasi Kependudukan adalah rangkaian kegiatan penataan dan penertiban dalam penerbitan dokumen dan data kependudukan melalui 
Pendaftaran Penduduk, Pencatatan Sipil, pengelolaan informasi Administrasi kependudukan serta pendayagunaan hasilnya untuk pelayanan publik dan pembangunan sektor lain sebagaimana hal ini termaktub dalam pasal 1 ayat (1) Undang-Undang No. 23 Tahun 2006. Pelaksanaan administrasi tersebut harus sesuai prosedur dan dilaksanakan dengan baik kepada masyarakat. Administrasi kependudukan sebagai suatu sistem diharapkan dapat diselenggarakan sebagai bagian dari penyelenggaraan Administrasi Negara. Dari segi kepentingan penduduk administrasi kependudukan memberikan pemenuhan hak-hak administratif, seperti pelayanan publik serta perlindungan yang berkenaan dengan dokumen kependudukan, tanpa adanya perlakuan yang diskriminatif (Undang-Undang No. 23 Tahun 2006).

Hal yang terjadi dilapangan masih ditemukan hak pelayanan yang diterima oleh masyarakat terasa belum memenuhi harapan dari kalangan masyarakat umum maupun dari kalangan pemerintah sendiri. Pelayanan masyarakat yang diberikan oleh pihak kelurahan masih cenderung rumit baik dari tata cara pelayanan, rendahnya pendidikan pegawai, kurangnya sarana dan prasarana, kurangnya jumlah pegawai dan disiplin kerja. Pelayanan masyarakat dapat dikatakan efektif jika semua aspek tersebut terpenuhi. Namun di daerah desa yang merupakan entitas pemerintahan yang langsung berhubungan dengan rakyat, namun secara geografis berjarak cukup jauh dari pusat kekuasaan di tingkat atasnya. Masih sulit untuk memenuhi sumber daya manusia yang memiliki keahlian, keterampilan/ kemampuan dan pemahaman sesuai bidang dan pekerjaan yang dijalankan serta sulitnya memenuhi sarana dan prasarana yang kurang. Melihat pemasalahan yang ada di kelurahan Bunut yaitu minimnya peralatan kantor seperti komputer dan printer, tata kelola pengarsipan yang belum benar, masih kurangnya pegawai kelurahan serta masih rendahnya tingkat pendidikan pegawai kelurahan. Hal ini mendorong penulis untuk mengetahui seberapa jauh efektivitas pelayanan kelurahan dalam memberikan pelayanan administrasi kependudukan kepada masyarakat keluruhan Bunut yang memerlukannya. Disamping itu penulis juga ingin mendeskripsikan bagaimana kinerja pegawai kelurahan, baik dari kepala lurah, sekretaris lurah dan pegawai bersangkutan dalam pelayanan administrasi kependudukan. Adapun ruang lingkup penelitian adalah efektivitas peran kelurahan dalam pelayanan administrasi kependudukan yang berkaitan dengan kinerja pegawai dengan mengedepankan permasalahan yang ada seperti permasalahan tata cara pelayanan, rendahnya pendidikan pegawai, kurangnya sarana dan prasarana, kurangnya jumlah pegawai dan disiplin kerja terutama yang berada di kelurahan Bunut. Dari ruang lingkup diatas, maka penulis secara singkat dapat mengajukan permasalahan dalam penelitian ini yaitu sebagai berikut: "Bagaimanakah efektivitas peran kelurahan Bunut dalam pelayanan administrasi kependudukan?".

Mengacu pada teori Gibson dalam Thoha (2003) mengenai keefektifan, dikatakan bahwa kefektifan adalah penilaian yang dibuat sehubungan dengan prestasi individu, kelompok dan organisasi. Pegawai aparatur pemerintah sebagai seorang individu merupakan pelaku dalam efektivitas individu. Dalam prespektif kefektifan, dibagi dalam tiga tingkatan dan bagian yang paling mendasar adalah keefektifan individu. Kefektifan suatu kelompok akan ditentukan oleh keefektifan individu dan kefektifan organisasi tergantung pada keefektifan kelompok. Selanjutnya dalam Undang-Undang Nomor 23 tahun 2014 tentang Pemerintahan Daerah menjelaskan bahwa kelurahan adalah suatu wilayah yang ditempati oleh sejumlah penduduk dengan kesatuan masyarakat hukum yang mempunyai organisasi pemerintah terendah langsung di bawah camat yang tidak berhak menyelenggarakan rumah tangganya sendiri dalam Negara Kesatuan Republik Indonesia. Kelurahan adalah wilayah kerja lurah sebagai perangkat daerah kabupaten atau kota. Kelurahan dipimpin oleh seorang lurah yang berstatus sebagai Pegawai Negeri Sipil (PNS). Kelurahan berada di wilayah perkotaan. Dalam hubungan ini maka, fungsi pemerintah sangat diharapkan dapat memenuhi kebutuhan tersebut, mengenai fungsi-fungsi pemerintah yang lain yaitu pemerintah kelurahan berfungsi melayani kebutuhan warga negara yang bersangkutan komoditas yang diharapkan dari pemerintah, misalnya keadilan, keamanan dan lain sebagainya. Selanjutnya dalam bukunya Poltak,dkk (2008) mengatakan bahwa kualitas 
pelayanan berhubungan erat dengan pelayanan yang sistematis dan komprehensif yang dikenal dengan konsep pelayanan prima dimana aparat pelayanan semestinya dapat memahami variabel-variabel pelayanan yaitu pemerintahan yang bertugas melayani; masyarakat yang dilayani pemerintah; kebijaksanaan yang dijadikan landasan pelayanan publik; peralatan atau sarana pelayanan yang canggih; resources yang tersedia untuk diracik dalam bentuk kegiatan pelayanan; kualitas layanan yang memuaskan masyarakat sesuai dengan standar dan asas pelayanan masyarakat; manajemen dan kepemimpinan serta organisasi pelayanan masyarakat; perilaku pejabat yang terlibat dalam pelayanan masyarakat apakah masing-masing sudah menjalankan fungsinya.

Untuk melihat sejauh mana efektivitas kinerja pegawai kelurahan Bunut dalam pelayanan administrasi kependudukan dapat diukur dengan melihat beberapa indikator yang ada. Ada beberapa faktor keberhasilan efektivitas yang dapat saling mempengaruhi dan berkesinambungan untuk tercapainya kinerja pegawai kelurahan Bunut dalam pelayanan administrasi kependudukan. Faktor yang pertama adalah masukan (input). Input dari kinerja pelayanan administrasi kependudukan dapat berupa fasilitas sarana dan prasarana, berupa ruangan dan alat-alat yang dibutuhkan untuk melakukan proses sampai menghasilkan hasil akhir, material (bahan baku) berupa data-data administrasi kependudukan yang diperlukan yang nantinya akan diolah menjadi sebuah informasi, dan yang terakhir sumber daya manusia harus berkualitas sebagai aparatur penyelenggara pelayanan. Faktor berikutnya adalah proses produksi dimana merupakan kegiatan untuk menciptakan kegunaan dari komponen-komponen input yang telah disebutkan diatas, dengan melakukan kegiatan-kegiatan yang dapat menambah kegunaan dari input seperti komunikasi, dan pengambilan keputusan. Hasil (output) merupakan bentuk dari input kemudian diolah menjadi data sehingga memiliki berbagai macam bentuk output-nya. Hasil yang dapat dilihat dari perbandingan antara masukan (input) dan keluaran (output), keluaran yang dihasilkan dicapai dari masukan yang melakukan proses kegiatan yang bentuknya secara umum dapat berupa: produk yaitu berupa barang dan berupa jasa atau dalam bentuk pelayanan yang diberikan instansi pemerintah sebagai penyelenggara pelayanan.

\section{METODE PENELITIAN}

Metode penelitian ini menggunakan metode deskriftif dengan pendekatan penelitian kualitatif, yaitu menggambarkan, menerangkan/menjelaskan dan menjawab secara rinci permasalahan yang diteliti dengan mempelajari semaksimal mungkin seorang individu atau suatu kelompok atau suatu kejadian, dimana peneliti merupakan instrumen kunci dan hasil penelitian merupakan rangkaian kata-kata atau pernyataan yang sesuai dengan keadaan sebenarnya. Adapun subyek dalam penelitian ini adalah kepala kelurahan dan para pegawai kelurahan Bunut serta masyarakat kelurahan Bunut yang mendapat pelayanan administrasi kependudukan. Obyek penelitian ini yaitu aktifitas pelayanan administrasi kependudukan yang diberikan oleh kelurahan bunut kepada masyarakat kelurahan Bunut. Informan penelitian dalam penelitian ini responden dipilih secara sengaja yang terdiri dari beberapa informan yang dianggap memiliki pengetahuan yang baik tentang kinerja pegawai kelurahan dalam pelayanan administrasi kependudukan di Bunut kabupaten Sanggau yaitu sekretaris lurah dan kepala seksi pemerintahan. Selanjutnya teknik pengumpulan data merupakan langkah penting dalam melakukan penelitian, karena data yang terkumpul akan dijadikan bahan analisis dalam penelitian. Metode yang digunakan dalam penelitian kualitatif ini adalah dengan teknik triangulasi data, yaitu dengan wawancara semi terstruktur, pengamatan (observasi) langsung terhadap aktifitas pelayanan administrasi kependudukan di kelurahan Bunut, dan dengan dokumentasi. Dan alat pengumpul data berupa pedoman wawancara, pedoman observasi, dan dengan dokumentasi berupa foto dan tape recorder. Teknik analisis data yang digunakan dalam penelitian ini adalah analisis kualitatif yang digunakan peneliti sebagaimana yang dikemukakan Miles dan Hubberman (Sugiyono, 2012) yaitu pengumpulan data, reduksi data, penyajian data dan langkah terakhir adalah penarikan kesimpulan. 


\section{HASIL DAN PEMBAHASAN}

Hampir setiap hari ada saja warga kelurahan Bunut yang mengurus surat-surat administrasi kependudukan seperti surat untuk melanjutkan pendidikan, surat berkelakukan baik, surat keterangan pindah, surat keterangan tidak mampu, surat keterangan kelakuan baik, surat keterangan belum menikah, surat keterangan lahir, dan surat keterangan lainnya. Untuk membuat surat adminitrasi kependudukan tersebut masyarakat harus melampirkan beberapa syarat untuk memenuhi surat yang diperlukan. Persyaratan itu harus dilengkapi oleh masyarakat yang bersangkutan, untuk membuat surat administrasi kependudukan yang diperlukan. Proses pembuatan surat menyurat di kantor Lurah Bunut dibuat selama pengamatan peneliti ada yang dilayani dalam hitungan menit dan ada pula yang dilayani dalam hitungan jam bahkan ada yang perlu beberapa hari baru selesai dikerjakan tergantung jenis surat yang dibuat. Dalam hal ini warga masyarakat yang membutuhkan pelayanan tentunya ingin mendapatkan pelayanan yang cepat dan tudak susah dalam pengurusannya dan tentu saja bebas biaya administrasinya. Adapun data-data yang dapat peneliti sajikan dari penelitian ini guna mendukung hasil dan tujuan penelitian ini tentang efektivitas pelayanan administrasi kependudukan di kelurahan Bunut dijelaskan dibawah ini.

\section{Hasil}

Jumlah penduduk kelurahan Bunut kabupaten Sanggau berjumlah 7.941 jiwa. Dengan 4.334 penduduk laki-laki dan 3.607 penduduk perempuan. Jumlah Rukun Tetangga (RT) di kelurahan Bunut ada 22 Rukun Tetangga (RT).

Berikut ini akan di jelaskan jumlah penduduk Kelurahan Bunut berdasarkan usia, yaitu :

Tabel 1. Jumlah Penduduk Berdasarkan Usia

\begin{tabular}{clc}
\hline No. & \multicolumn{1}{c}{ Rentang Usia } & Jumlah (jiwa) \\
\hline 1. & Usia $0-15$ tahun & 764 \\
& & 1.414 \\
2. & Usia $16-55$ & 319 \\
3. & Usia di atas 55 tahun \\
\hline
\end{tabular}

Adapun jumlah masyarakat yang di lihat dari keragaman dalam beragama. Dari jumlah masyarakat 7.941 jiwa ada beberapa kategori agama yang dipercayai masyarakat, yaitu sebagai berikut :

Tabel 2. Jumlah Penduduk Berdasarkan Agama

\begin{tabular}{|c|c|c|}
\hline No. & Agama & Jumlah (jiwa) \\
\hline & Islam & 2040 \\
\hline 2. & Katolik & 351 \\
\hline 3. & Protestan & 80 \\
\hline 4. & Hindu & - \\
\hline 5. & Budha & 26 \\
\hline
\end{tabular}

Berdasarkan dari kategori usia dan jumlah masyarakat Kelurahan Bunut yang berjumlah 7.941 jiwa, dimana tidak dan belum semua masyarakat yang memiliki pendidikan, mengikuti pendidikan dan memperoleh status identitas pendidikan diberbagai jenjang pendidikan dibawah ini akan dijelaskan dan digambarkan keadaan jumlah penduduk berdasarkan pendidikan yang terdapat pada tabel 3 sebagai berikut:

Tabel 3. Jumlah Penduduk Berdasarkan Pendidikan

\begin{tabular}{crr} 
No. & Jenjang Pendidikan & Jumlah (jiwa) \\
\hline 1. & Belum Sekolah & 401
\end{tabular}


2. Tidak tamat SD

3. Tamat SD 998

4. Tamat SMP

5. Tamat SMA

6. Tamat Perguruan Tinggi

Gambaran data tentang jumlah masyarakat Kelurahan Bunut berdasarkan angkatan kerja dapat dilihat pada tabel 4 berikut ini :

\begin{tabular}{clc}
\multicolumn{3}{l}{ Tabel 4. Jumlah Penduduk Berdasarkan Angkatan Kerja } \\
\hline No. & \multicolumn{1}{c}{ Angkatan Kerja } & Jumlah (jiwa) \\
\hline 1. & $\begin{array}{l}\text { Penduduk usia 15-55 tahun yang } \\
\text { masih sekolah }\end{array}$ & 752 \\
2. & $\begin{array}{l}\text { Penduduk usia 15-55 tahun yang } \\
\text { menjadi ibu rumah tangga }\end{array}$ & 777 \\
3. & $\begin{array}{l}\text { Penduduk usia 15-55 tahun yang } \\
\text { bekerja penuh }\end{array}$ & 775 \\
4. & $\begin{array}{l}\text { Penduduk usia 15-55 tahun yang } \\
\text { bekerja tidak penuh }\end{array}$ & 193 \\
\end{tabular}

Adapun jumlah keadaan masyarakat yang dapat digambarkan dari mata pencaharian, dimana dari jumlah masyarakat kelurahan Bunut 7.941 jiwa tersebar dalam beberapa kategori mata pencaharian masing-masing, di dalam data tabel 5 yang diperoleh peneliti dari kantor Lurah Bunut digambarkan kurang lebih ada 9 (sembilan) kategori kelompok mata pencaharian, masyarakat yang dilakukannya. Berikut gambaran jumlah masyarakat berdasarkan mata pencaharian yaitu :

\begin{tabular}{clr}
\multicolumn{2}{c}{ Tabel 5. Jumlah Penduduk Berdasarkan Mata Pencaharian } \\
\hline No. & \multicolumn{1}{c}{ Mata Pencaharian } & Jumlah (jiwa) \\
\hline 1. & Buruh tani & 79 \\
2. & Petani & 417 \\
3. & Peternak & - \\
4. & Pedagang & 25 \\
5. & Nelayan & 8 \\
6. & PNS & 5 \\
7. & Pengrajin & - \\
8. & Montir & 4 \\
9. & Buruh swasta & 79 \\
\hline
\end{tabular}

Data tentang prasarana dan sarana pendidikan di kelurahan Bunut peneliti juga peroleh berdasarkan data buku administrasi kelurahan, kelompok prasarana dan sarana pendidikan yang ada di kelurahan Bunut terdapat dalam tabel 6, digambarkan ada 11 (sebelas) jenis prasarana dan sarana pendidikan, secara jelas gambaranya dapat di lihat dalam tabel 6 sebagai berikut:

Tabel 6. Sarana dan Prasarana Pendidikan

\begin{tabular}{crc}
\hline No. & \multicolumn{1}{c}{ Jenis } & Jumlah \\
\hline 1. & Gedung Kampus PTN & - \\
2. & Gedung Kampus PTS & 2 \\
3. & Gedung SMA/sederajat & 4
\end{tabular}


4. Gedung SMP/sederajat 3

5. Gedung SD/sederajat 4

6. Gedung TK

7. Gedung Tempat bermain anak -

8. Jumlah Lembaga Pendidikan Agama -

9. Jumlah perpustakaan keliling -

10. Perpustakaan desa/kelurahan -

11. Taman bacaan

Keberadaan data untuk prasarana dan sarana pemerintahan desa dari hasil data yang peneliti peroleh juga memberikan keberadaan kondisi dan gambaran yang heterogen dan beraneka ragam dalam wujud dan bentuk prasarana dan sarana yang ada dan belum ada, dan bermacam-macam kondisi lainnya. Untuk jelasnya dapat di lihat tentang gambaran prasarana dan sarana pemerintahan desa yaitu dapat dilihat dalam tabel 7 sebagai berikut:

Tabel 7. Sarana dan Prasarana Pemerintahan Desa

\begin{tabular}{|c|c|c|c|}
\hline No. & Nama Sarana dan Prasarana & Jumlah & Keterangan \\
\hline 1. & Gedung Kantor Lurah & 1 & Unit \\
\hline 2. & Kondisi & & Baik \\
\hline 3. & Jumlah ruang kerja & 4 & Ruang \\
\hline 4. & Listrik & & Ada \\
\hline 5. & Air bersih & & Ada \\
\hline 6. & Telepon & & tidak ada \\
\hline 7. & Rumah Dinas Kepala Lurah & & tidak ada \\
\hline 8. & Rumah Dinas Perangkat Desa & & tidak ada \\
\hline 9. & Inventaris dan Alat Tulis Kantor & & \\
\hline 10. & Jumlah Mesin Tik & 1 & Buah \\
\hline 11. & Jumlah meja & 8 & Buah \\
\hline 12. & Jumlah kursi & 16 & Buah \\
\hline 13. & Jumlah lemari arsip & 6 & Buah \\
\hline 14. & Komputer & 1 & Unit \\
\hline 15. & Mesin fax & - & \\
\hline 16. & Kendaraan dinas & - & \\
\hline 17. & Printer & 1 & Unit \\
\hline 18. & $\begin{array}{l}\text { Administrasi Pemerintahan } \\
\text { Kelurahan }\end{array}$ & & \\
\hline 19. & Buku data peraturan Kelurahan & & ada/tidak,terisi/tidak \\
\hline 20. & Buku Keputusan Kepala Lurah & & ada/tidak,terisi/tidak \\
\hline 21. & Buku Administrasi Kependudukan & & ada/tidak,terisi/tidak \\
\hline 22. & Buku Data Inventaris & & ada/tidak,terisi/tidak \\
\hline
\end{tabular}

Potensi kelembagaan pemerintahan kelurahan Bunut juga terbagi dalam beberapa katagori dan kelompok seperti katagori pemerintah kelurahan, tingkat pendidikan aparatur kelurahan, keberadaan lembaga Badan Permusyawaratan Desa (BPD), semua ini memberikan keadan kondisi masing-masing, secara jelas gambaran data realitasnya tentang potensi kelembagaan pemerintahan desa dapat kita pahami dalam tabel 8 berikut:

Tabel 8. Potensi Kelembagaan Pemerintahan Desa

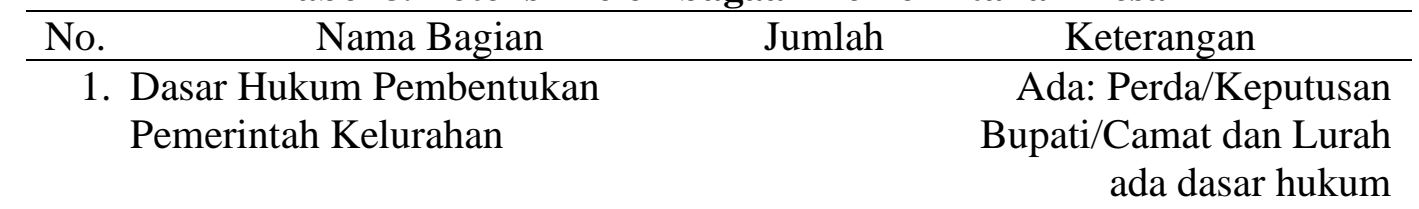




\begin{tabular}{lrr} 
2. Jumlah aparatur kelurahan & 8 & orang \\
3. Jumlah Perangkat Kelurahan & 14 & unit kerja \\
4. Kepala Lurah & 1 & orang \\
5. Sekretaris Lurah & 1 & orang \\
6. Kepala Seksi Pemerintahan & 1 & orang \\
7. Kepala Seksi Pembangunan & 1 & orang \\
8. Kepala Seksi Pemberdayaan & 1 & orang \\
$\quad$ Masyarakat & & \\
9. Kepala Seksi kesejahteraan rakyat & 1 & orang \\
10. Kepala Seksi umum & - & tidak ada \\
11. Kepala Seksi Keuangan & 1 & orang \\
12. Jumlah staf & 3 & orang \\
\hline
\end{tabular}

Dibawah ini adalah data tingkat pendidikan pegawai kelurahan Bunut sebagai berikut:

Tabel 6. Tingkat Pendidikan Pegawaian Keluruhan

\begin{tabular}{llc}
\hline No & \multicolumn{1}{c}{ Jabatan } & Tingkat Pendidikan \\
. & \multicolumn{1}{c}{ S-1 } \\
1. & Kepala Lurah & S1 \\
2. & Sekretaris Lurah & SMA \\
3. & Kepala Seksi Pemerintahan & SMA \\
4. & Kepala Seksi Pembangunan & SMA \\
5. & Kepala Seksi Pemberdayaan & \\
& Masyarakat & SMA \\
6. & Kepala Seksi Kesejahteraan Rakyat & - \\
7. & Kepala Seksi Umum & SMA \\
8. & Kepala Seksi Keuangan & \\
\hline
\end{tabular}

\section{Pembahasan}

Merujuk pada hasil penelitian sebelumnya antara lain penelitian studi kasus oleh Rahmawati, dkk (2021) di kelurahan Samaan kecamatan Klojen kota Malang tentang efektifitas pelayanan publik bidang administrasi kependudukan di masa pandemi Covid-19 dikatakan bahwa faktor pendukung efektivitas pelayanan publik bidang administrasi kependudukan di kelurahan Samaan yaitu faktor sumber daya yang cukup memadai; faktor sarana dan prasarana yang ada sudah memadai; faktor petugas pelayanan yang ramah dan berkompeten, sedangkan faktor penghambat dari efektivitas pelayanan publik di bidang administrasi kependudukan di kelurahan Samaan yaitu faktor kurangnya sosialisasi kepada masyarakat serta kurangnya pemahaman masyarakat itu sendiri akan kemajuan teknologi. Selanjutnya pada penelitian yang dilakukan oleh Mustafa, dkk (2020) di kelurahan Merjosari kecamatan Lowokwaru kota Malang tentang efektivitas pelayanan administrasi kependudukan dalam meningkatkan tata Kelola pemerintahan yang baik (studi pelayanan KK, KTP/e-KTP dan akta kelahiran di kelurahan Merjosari kecamatan Lowokwaru kota Malang) menjelaskan bahwa faktor pendukung pelayanan ialah meliputi media, sarana dan prasarana serta faktor kemampuan Sumber Daya Alam (SDA) yang mumpuni, sedangkan faktor penghambat pelayanan ialah faktor keterbatasan Sumber Daya Manusia (SDM) dan faktor kesadaran masyarakat serta faktor kurangnya pemahaman tugas pokok dan fungsi (TUPOKSI) pelayanan. Adapun penelitian lain yang relevan adalah penelitian yang dilakukan oleh Nuraini (2021) tentang efektivitas pelayanan publik pada kantor kelurahan Leok 1 kecamatan Biau kabupaten Buol menjelaskan bahwa ketepatan waktu dan tingkat kedisiplinan pegawai kelurahan merupakan faktor pendukung utama terselenggaranya pelayanan publik yang efektif dan efisien serta tingkat responsivitas pegawai kelurahan dalam melakukan proses pelayanan publik. 
Adapun berdasarkan hasil survei dan wawancara serta dokumentasi yang dilakukan oleh peneliti di kantor kelurahan Bunut maka efektivitas peran kelurahan dalam pelayanan administrasi kependudukan dapat di ukur dari indikator berikut yaitu indikator peralatan dan sarana dan prasarana berkaitan dengan penyediaan peralatan kantor yaitu komputer dan printer, penyediaan loker atau lemari buku untuk menyimpan data-data atau berkas surat administrasi kependudukan, dan penyediaan ruangan kantor Lurah Bunut. Dari hasil survei di kantor Lurah Bunut, gedung kantor masih terlihat terawat, bagus dan tertata cukup rapi, namun pengarsipan yang masih belum tertata. Di kantor Lurah Bunut memiliki 3 ruangan, yaitu ada ruangan Kepala Lurah, ruangan Sekretaris Lurah, dan ruangan Tata Usaha (TU) yang berada di tengah secara terbuka tempatnya tanpa sekat. Tersedia juga meja dan kursi kerja sebanyak 8 unit untuk staf kantor Lurah. Selain itu, tersedia lemari untuk menyimpan berkas dan data-data penting, dan kursi tunggu, kursi tamu dan kipas angin. Adapun peralatan kantor yang tersedia yaitu berupa 1 unit mesin tik, 1 unit komputer dan 1 unit printer yang digunakan untuk membuat, mencetak, dan menyimpan file data administrasi kependudukan Kelurahan Bunut. Menurut Kasi Pemerintah kelurahan Bunut yaitu Ibu Maria Goreti bahwa peralatan dan sarana prasarana di kelurahan Bunut masih belum memadai, seperti peralatan komputer dan printer hanya 1 (satu) unit saja, jika banyak warga yang datang harus sabar mengantri. Dengan adanya komputer dan printer di mana penggunaannya bisa lebih praktis dibanding mesin tik yang kami punya. Pekerjaan dalam melayani pembuatan surat-menyurat yang diperlukan masyarakat juga dapat dibuat dengan waktu yang singkat dengan adanya komputer dan printer sehingga masyarakat Bunut yang datang tidak perlu menunggu lama. Kemudian beliau mengatakan bahwa ruangan di kantor ini ada 4 ruangan, tetapi hanya 3 ruangan yang di fungsikan sebagai ruangan kerja. Sedangkan 1 ruangan lagi memang sengaja di khususkan untuk jabatan tertentu karena ruangan itu difungsikan untuk ruangan PKK dan untuk menyimpan peralatan PKK sedangkan tempat kerja Kasi kelurahan ditempatkan ditengah ruangan kantor agar mempermudah aktivitas pelayanan kepada masyarakat, karena kantor Lurah ini tidak terlalu besar. Di ruangan tersebut juga kami posisikan untuk tempat kursi tunggu masyarakat dan tempat untuk menerima tamu. Selanjutnya indikator material, yang berkaitan dengan penyediaan data-data administrasi kependudukan Kelurahan Bunut. Berdasarkan hasil wawancara dengan Sekretaris Lurah Bunut, bapak Julius Soebolon, S.Sos mengatakan, "di kantor Lurah ini data-data yang berkaitan dengan kependudukan sudah dibuat sesuai hasil pendataan dilapangan yang dilakukan oleh pihak RT kepada masyarakatnya, dari RT melapor ke pihak kelurahan Bunut. Data-data tersebut juga kami olah dan simpan di komputer. Jadi untuk pihak masyarakat yang berkepentingan suatu saat memerlukan data kependudukannya, kami pihak kelurahan dapat membantu dan memenuhi data yang diperlukannya dengan segera. Kemudian untuk surat-menyurat yang berhubungan dengan administrasi kependudukan dan belum dicetak (printout), staf kelurahan sudah menyediakan dan sudah membuat blangko dari surat-menyurat itu, jika masyarakat yang bersangkutan datang, kami disini siap dan langsung membuat kan surat yang di perlukan oleh masyarakat tersebut. Jadi, masyarakat tidak perlu menunggu lama. Data yang berkaitan dengan surat-menyurat yang bersangkutan juga sudah kami kumpulkan dan simpan sebagai data dokumentasi kelurahan. Indikator selanjutnya adalah indikator Sumber Daya Manusia (SDM), yang berkaitan dengan tingkat pendidikan dan jumlah tenaga kerja di kelurahan Bunut. Digambarkan susunan struktur organisasi kelurahan Bunut yang terdiri dari Lurah, Sekretaris, Kasi Pemerintahan, Kasi Ekonomi Pembangunan (EKBANG), dan Kasi Kesejahteraan Rakyat (KESRA). Masing-masing kasi memiliki satu staf. Lurah dan staf pegawai disini memiliki tugas dan tanggung jawab yang berbeda.Untuk menghasilkan kinerja yang baik diperlukan staf pegawai dengan kriteria yaitu, lulusan pendidikannya minimal adalah diploma, sesuai bidang pendidikannya, memiliki keahlian komputer dan diperlukan juga kerja sama yang baik antar staf kelurahan. Dari hasil penelitian dapat diketahui bahwa ada beberapa staf yang tingkat pendidikan terakhirnya adalah SMA, dan tidak pandai mengaplikasikan komputer. Pendidikan Lurah hanya tamatan SMA, sekretaris lurah tamatan S1, Kasi Kesra tamatan D3 dan saat ini sedang melanjutkan pendidikan S1, staf Ekbang tamatan D3 dan statusnya masih honor, 
selebihnya tamatan SMA. Ini sesuai dengan yang dikatakan oleh Kasi Kesra yaitu Ibu Cirila Sriani, A.Md, "ada beberapa staf kelurahan yang bekerja disini hanya tamatan SMA. Tetapi ada juga yang lulusan/ tamatan Sarjana. Meskipun demikian tugas dan pekerjaan yang mereka kerjakan dapat diselesaikan dengan penuh tanggung jawab. Apapun pekerjaan di masingmasing Kasi (Kepala Seksi) juga bisa berjalan dengan efektif. Kami disini saling mendukung dan membantu dalam bekerja. Bahkan staf kami yang kualifikasi pendidikannya sarjana, dan dapat menggunakan serta mengaplikasikan komputer juga bersedia membimbing, mengarahkan dan membantu staf lain apabila mengalami kesulitan dalam bekerja. Kepala Lurah disini juga selalu memberikan motivasi, masukan, arahan dan bimbingan agar semua staf di kantor ini bisa bekerja dan memberikan pelayanan dengan lebih baik lagi. Karena hal tersebut dapat mempengaruhi kredibilitas masyarakat kepada kelurahan, dan meningkatkan citra kelurahan di pandangan masyarakat". Jumlah staf pegawai di kantor Lurah ini berjumlah 6 orang, dimana masing-masing Kasi terdiri dari 1 orang staf. Jabatan lurah saat ini dihandel oleh sekretaris lurah dikarenakan baru 4 bulan yang lalu kepala lurahnya meninggal dunia. Pelayanan yang dilakukan Kasi Pemerintahan, Kasi Ekonomi Pembangunan (EKBANG), dan Kasi Kesejahteraan Rakyat (KESRA) memiliki tugas dan pelayanan administrasi kependudukan yang berbeda. Walaupun jumlah staf terbilang sedikit, pelayanan diberikan secara bergantian kepada masyarakat dan sejauh ini tidak mempengaruhi proses pelayanan di kantor Lurah Bunut. Masyarakat juga mengerti dan bersedia menunggu antrean untuk mendapatkan surat-menyurat yang di perlukannya. Menurut Kasi Kesra bahwa di kantor Lurah ini memang fasilitas dan jumlah staf sedikit, hal tersebut tidak menjadi kendala, kami selalu bekerja dengan siap siaga dengan tidak bertele-tele pada saat membuat surat-menyurat yang di perlukan oleh masyarakat, kami tidak ingin membuat masyarakat menunggu lama".

Indikator selanjutnya untuk mengukur efektivitas peran kelurahan dalam pelayanan administrasi kependudukan yaitu berkaitan dengan proses komunikasi dan pengambilan keputusan di kantor Lurah Bunut. Pertama, komunikasi yang terjadi di kantor Lurah Bunut, sebelum melakukan pelayanan administrasi kependudukan, pihak kelurahan akan memberitahukan kepada setiap masyarakat yang datang untuk mengurus surat-menyurat nya, ada beberapa syarat yang harus dipenuhi mereka. Selain itu pihak kelurahan juga akan menjelaskan prosedur pengurusan surat-menyurat tersebut. Setelah syarat yang dipenuhi oleh masyarakat sudah ada dan lengkap, pihak kelurahan akan segera membuatkan surat yang diperlukan masyarakat tersebut. Menurut Kasi Pemerintahan, "setiap pelayanan administrasi kependudukan apapun surat yang akan di buat dan di cetak oleh kelurahan, ada beberapa syarat yang harus dipenuhi oleh masyarakat, salah satu nya masyarakat harus melampirkan surat pengantar/ keterangan dari RT setempat, dan masih banyak syarat-syarat yang lain. Hal ini sudah kami sampaikan secara langsung kepada masyarakat saat datang ke kantor untuk mengurus surat menyurat yang diperlukan. Apabila syarat surat yang diminta hilang, kami akan memberitahukan dan mengarahkan kemana seharusnya masyarakat pergi untuk mengurus surat yang hilang itu. Agar syarat tersebut bisa segera dipenuhi dan masyarakat dapat segera memiliki surat yang mereka perlukan". Kedua, berkaitan dengan pengambilan keputusan, jika peryaratan pembuatan surat-menyurat administrasi kependudukan sudah di lengkapi, maka pihak Kelurahan akan segera membuat surat yang bersangkutan. Surat menyurat yang telah selesai dicetak, harus diketahui oleh Kepala Lurah Bunut, dengan di tanda tangani surat tersebut, maka surat yang diminta pun sudah selesai dan boleh dibawa pulang serta digunakan sesuai dengan keperluan masyarakat tersebut. Untuk semua kegiatan administrasi kependudukan di kantor lurah Bunut, prosedur pelayanan nya di mulai dari RT (Rukun Tetangga) setempat sesuai tempat tinggal masyarakat tersebut dan langsung ke kelurahan ditangani oleh staf kelurahan untuk memeriksa syarat yang dipenuhi sudah lengkap atau belum, jika berkas-berkas surat yang dilampirkan sudah lengkap, maka staf Kasi bersangkutan akan membuat surat administrasi kependudukan yang diminta oleh masyarakat tersebut, kemudian surat yang sudah di cetak akan di serahkan kepada Lurah untuk di cek kembali apakah surat tersebut sudah sempurna, jika sudah akan segera di tanda tangani oleh Lurah. Dapat disimpulkan bahwa pengambilan 
keputusan di kantor Lurah Bunut di tentukan dari masing-masing Kasi kelurahan Bunut, dan disetujui oleh Lurah. Dari penjelasan di atas dapat disimpulkan bahwa Efektivitas Peran Kelurahan dalam Pelayanan Administrasi Kependudukan di Kelurahan Bunut Kabupaten Sanggau sejauh ini masih dapat dikatakan efektif. Hal tersebut disebabkan oleh pelayanan di kantor Lurah Bunut didukung oleh tersedianya peralatan sarana dan prasarana, seperti komputer dan printer yang membantu proses pembuatan surat-menyurat lebih praktis dan cepat dibandingkan dengan mesin tik. Kemudian tersedianya data-data berupa surat menyurat administrasi kependudukan yang diperlukan oleh masyarakat. Selain itu, walaupun staf di kantor Lurah Bunut sebagian besar kualifikasi pendidikannya adalah tamatan/lulusan SMA dan tidak semua staf yang bisa mengaplikasikan komputer, hal itu tidak menjadikan pelayanan di kantor Lurah Bunut bermasalah, hal itu masih bisa diimbangi dengan attitude dari staf kelurahan yang baik serta kerjasama antar pegawai yang bisa mengoperasikan komputer dengan pegawai yang tidak pandai.

\section{KESIMPULAN}

Dari beberapa indikator yang sudah dijelas diatas, maka dapat disimpulkan bahwa pelayanan administrasi kependudukan yang dilakukan oleh kelurahan Bunut sejauh ini dapat berjalan dengan efektif,namun ada beberapa kendala yang ditemui di lapangan di mana terdapat kendala dengan peralatan kantor seperti komputer dan printer yang kurang memadai dan masih kurangnya Sumber Daya Manusia (SDM). Proses pelayanan di Kantor Lurah Bunut dapat dilaksanakan dengan baik apabila dalam pelayanan yang dilakukan didukung oleh fasilitas peralatan dan sarana prasarana di kantor, didukung oleh penyediaan berkas dan data-data yang mendukung penyediaan perangkat data di kelurahan, didukung oleh pelayanan yang diberikan oleh staf pegawai kepada masyarakat yang ditunjukkan dengan kinerja dan keramahan pada saat melayani masyarakat. Semua aspek itu yang membuat peran kelurahan dalam pelayanan administrasi kependudukan di Bunut sejauh ini dapat dikatakan efektif. Agar pelayanan administrasi di kelurahan Bunut dapat berjalan dengan efektif maka diharapkan kepada pemerintahan kelurahan Bunut untuk terus menjaga kualitas pelayanan kepada masyarakat agar lebih baik dari sebelumnya dengan meningkatkan tingkat atau jenjang pendidikan pegawai atau staf yang ada di kantor Lurah Bunut. Pegawai diberikan kesempatan atau didorong untuk melanjutkan pendidikannya ke jenjang yang lebih tinggi lagi. Selain itu pegawai kelurahan Bunut agar diberikan pelatihan-pelatihan (workshop) tentang administrasi kependudukan dan keterampilan keahlian lainnya yang berkaitan dengan tugas dan fungsi di seksi mereka masingmasing. Di samping itu diharapkan kepada pemerintahan kabupaten Sanggau dan kelurahan Bunut khususnya bisa menyediakan atau menambah peralatan dan sarana prasarana yang ada di kantor Lurah Bunut seperti komputer dan printer agar proses pelayanan dapat berjalan lebih efektif dan dapat lebih mempermudah pekerjaan staf baik dalam menyediakan dan menyimpan data-data surat-surat serta meningkatkan kompetensi pegawai kelurahan dengan memberikan pelatihan-pelatihan terkait administrasi kependudukan serta memberikan kesempatan dan mensupport para pegawai kelurahan untuk meningkatkan jenjang pendidikan mereka ke jenjang yang lebih tinggi.

\section{DAFTAR PUSTAKA}

Mathis, R. L., dan J. H. Jackson. (2006). Human Resource Management: Alih Bahasa. Jakarta: Salemba Empat

Moenir. (2001). Manajemen Pelayanan Umum di Indonesia. Jakarta: Bumi Aksara.

Mustofa, F., Afifuddin., \& Hayat (2020). Efektivitas Pelayanan Administrasi Kependudukan Dalam Meningkatkan Tata Kelola Pemerintah yang Baik (Studi Pelayanan KK, KTP/E-KTP dan Akta Kelahiran di Kelurahan Merjosan Kecamatan Lowokwaru Kota Malang). Respon Publik. 14(3), 14-26, from http://www.riset.unisma.ac.id/index.php/rpp/article/view/7920 
Nurani, Andi. (2021). Efektivitas Pelayanan Publik Pada Kantor Kelurahan Elok 1 Kecamatan Biau Kabupaten Buol. Jurnal Inovasi Penelitian. 1(12), 2567-2574, from DOI: https://doi.org/10.47492/jip.v1i12.520

Poltak, Lijan Sinambela, dkk. (2008). Reformasi Pelayanan Publik. Jakarta: Bumi Aksara.

Rahmawati, L., Umi, A.N., \& Suyeno. (2021). Efektivitas Pelayanan Publik Bidang Administrasi Kependudukan di Masa Pandemi Covid-19 (Studi Kasus Pada Kelurahan Samaan Kecamatan Klojen Kota Malang). Respon Publik. 15(9), 14-21, from http://www.riset.unisma.ac.id/index.php/rpp/article/view/12411

Rivai, Veithzal. (2006). Kepemimpinan dan Perilaku Organisasi. Jakarta: Raja Grafindo.

Safiie, Inu Kencana, (2003). Sistem Administrasi Negara Republik Indonesia. Jakarta: Bumi Aksara.

Siagian, Bondan P. (1992). Kerangka Dasar Ilmu Administrasi. Jakarta: Rineka Cipta.

Soekanto, Soejono. (1995). Penilaian Organisasi Pelayanan Publik. Yogyakarta: Pustaka Pelajar.

Sugiyono. (2012). Metode Penelitian Administrasi. Bandung: Alfabeta.

Suharto, Edi. (2006). Membangun Masyarakat Memberdayakan Rakyat. Bandung: Refika Aditama.

Thoha, Miftah. (2003). Perilaku Organisasi: Konsep Dasar Aplikasinya. Jakarta: Gramedia Pustaka.

Undang-Undang No. 23 Tahun 2006 tentang Administrasi Kependudukan. (2011). Bandung : Fokusmedia. 